SCENARIOS OF

THE IMAGINARY 
Digitized by the Internet Archive in 2017 with funding from Kahle/Austin Foundation

https://archive.org/details/scenariosofimagi00josu 


\section{SCENARIOS OF}

\section{THE IMAGINARY}

Theorizing the French Enlightenment

$$
\text { JOSUÉ V. HARARI }
$$

CORNELL UNIVERSITY PRESS 
Cornell University Press gratefully acknowledges a grant from the Andrew W. Mellon Foundation that aided in bringing this book to publication.

\section{Copyright (C) 1987 by Cornell University}

All rights reserved. Except for brief quotations in a review, this book, or parts thereof, must not be reproduced in any form without permission in writing from the publisher. For information, address Cornell University Press, I 24 Roberts Place, Ithaca, New York 14850.

First published 1987 by Cornell University Press.

International Standard Book Number o-80 1 4- I 842-9

Library of Congress Catalog Card Number 86-24247

Printed in the United States of America

Librarians: Library of Congress cataloging information appears on the last page of the book.

The paper in this book is acid-free and meets the guidelines for permanence and durability of the Committee on Production Guidelines for Book Longevity of the Council on Library Resources. 
For Jack G. Goellner 
